\title{
Melatih Literasi Matematis Siswa dengan Metode Naive Geometry
}

\author{
Maria Ulfa ${ }^{1}$, Ahmad Lubab $^{2}$, Yuni Arrifadah ${ }^{3}$ \\ ${ }^{1,2,3}$ Program Studi Pendidikan Matematika, UIN Sunan Ampel Surabaya
}

\begin{abstract}
The aim of this research is to measure mathematical literacy skills of a student after mathematics learning processes using naive geometry method on the quadratic equation. This research is using quantitative methods. This research was implemented at SMP Ulul Albab. The mathematical literacy skills obtained from observation and mathematics literacy tests which refer to the mathematics literacy indicator. The tests were given after a teaching and learning process using naive geometry while observation was done during the learning process. The results show that $22.73 \%$ students have high mathematical literacy skill, $68.18 \%$ students have intermediate mathematical literacy, and $9.09 \%$ students who have low math skills literacy.
\end{abstract}

Keywords: Naive geometry methods; Mathematical literacy

\section{PENDAHULUAN}

Hasil penilaian UN SMP tahun 2016 oleh Pusat Penilaian Pendidikan Kemendikbud menunjukkan bahwa nilai UN matematika masih rendah. Pemaparan Kepala Pusat Penilaian Pendidikan Kemendikbud, Nizam menyatakan bahwa dari tahun ke tahun nilai matematika selalu rendah sehingga hal ini menjadi pekerjaan rumah yang belum terselesaikan. Soal UN matematika tahun 2016 memiliki kualitas yang lebih tinggi dari tahun-tahun sebelumnya. Hal ini dikarenakan soal-soal tersebut memiliki daya penalaran yang lebih tinggi. Nizam dalam wawancaranya dengan Koran Jakarta menyebutkan bahwa 41,92\% siswa SMP berada pada tahap memahami apa yang diajarkan belum sampai pada tahap mengaplikasikan, apalagi tahap menalar (Nizam, Oktober 19, 2016)

Cara lain yang dilakukan untuk melihat kemampuan matematika siswa SMP adalah PISA. Berdasarkan hasil survey PISA pada tahun 2012, kemampuan matematika siswa di Indonesia masih rendah. Fokus penilaian PISA adalah pada aspek membaca, matematika, sains, dan pemecahan masalah. Penilaian yang dilakukan PISA bukan hanya memastikan apakah siswa dapat mengetahui apa yang mereka pelajari. Namun, lebih dari itu untuk melihat seberapa baik siswa mampu mengeksplorasi dan menerapkan apa yang telah dipelajari baik di dalam maupun di luar lingkungan sekolah. Kemampuan matematika siswa dalam PISA disebut dengan literasi matematis 
(Ayuningtyas, 2015).

Literasi matematis adalah kemampuan seseorang untuk merumuskan, menerapkan dan menafsirkan matematika dalam berbagai konteks. Termasuk kemampuan melakukan penalaran secara matematis dan menggunakan konsep, prosedur, dan fakta untuk menggambarkan, menjelaskan atau memperkirakan fenomena atau kejadian (Aini, 2013). Literasi matematis berfungsi untuk membantu siswa dalam memahami peran dan kegunaan matematika dalam kehidupan sehari-hari.

Survey PISA pada tahun 2012 menunjukkan bahwa siswa Indonesia menempati peringkat 64 dari 65 negara yang ikut berkontribusi. Siswa yang dijadikan subjek dalam survey ini adalah mereka yang berusia 15 tahun. Hampir seluruh siswa Indonesia ikut berpartisipasi, hasilnya 98,5\% siswa Indonesia hanya mampu mencapai kemampuan matematika PISA level 3 dari 6 level yang sudah ditetapkan (Ayuningtyas, 2015).

Siswa yang berada pada level 3 hanya mampu melaksanakan prosedur dengan baik dalam menyelesaikan soal serta dapat memilih strategi pemecahan masalah. Padahal diharapkan siswa telah berada pada level 4 yakni, siswa mampu bekerja secara efektif dengan model dan dapat memilih serta mengintegrasikan representasi yang berbeda, serta menghubungkannya dengan dunia nyata (Dafik \& Lestari, 2014). Belum banyak siswa Indonesia yang mencapai level 4. Hal ini menunjukkan bahwa siswa merasa kesulitan dalam membuat model matematika dan menghubungkan masalah matematika dengan dunia nyata. Salah satu penyebabnya adalah siswa belum terbiasa menyelesaikan masalah matematika yang langsung berkaitan dengan dunia nyata. Oleh karena itu perlu pembelajaran yang bermakna sehingga siswa mampu mengaitkan masalah matematika dengan dunia nyata. Salah satu solusi untuk memberikan pembelajaran yang bermakna yakni dengan memasukkan unsur sejarah didalamnya.

Banyak peneliti yang menyarankan penggunaan sejarah matematika dalam proses pembelajaran karena akan memberikan banyak keuntungan dalam proses pembelajaran (Kusumawati, 2015). Diantara keuntungan tersebut adalah sejarah bisa dijadikan sebagai objek cerita untuk menarik minat siswa dalam belajar. Selain itu, sejarah bisa dijadikan sebagai motivasi agar keinginan belajar siswa meningkat. Selanjutnya, sejarah bisa digunakan untuk menjelaskan materi abstrak yang dirasa sulit untuk dipahami siswa. Salah satu materi yang mampu diajarkan dengan sejarah adalah materi aljabar.

Aljabar adalah salah satu cabang matematika yang mempelajari penyederhanaan 
dan pemecahan masalah menggunakan simbol tertentu. Dalam aljabar tidak hanya menggunakan simbol angka, melainkan juga huruf ataupun kombinasi angka dan huruf. Berbagai bentuk model atau simbol dideskripsikan dalam aljabar. Kondisi ini seringkali menyebabkan anak kesulitan mengaitkan simbol aljabar dengan makna simbol tersebut (Kusaeri, 2012). Aljabar adalah salah satu materi yang diberikan kepada siswa kelas VIII berdasarkan KD kurikulum 2013.

Cholidah (2014) menyatakan bahwa saat belajar aljabar terdapat beberapa kesulitan yang dialami siswa, antara lain: (1) siswa tidak terbiasa dengan langkahlangkah aljabar, (2) siswa bingung dengan perbedaan penggunaan huruf pada aljabar, dan (3) siswa menemukan aljabar terlalu abstrak. Contoh kesulitan siswa SMP kelas VIII dalam belajar aljabar antara lain masih ada siswa yang menganggap bahwa $(a+b)^{2}$ adalah sama dengan $a^{2}+b^{2}$. Hal yang demikian menunjukkan bahwa siswa belum mengetahui makna dari operasi aljabar yang dia temui.

Metode naive geometry adalah salah satu sejarah matematika yang dapat dipakai untuk melatihkan kemampuan aljabar. Kusumawati (2014) menyatakan bahwa metode ini cocok digunakan dalam mempelajari materi persamaan kuadrat, khususnya dalam mencari akar-akar persamaan kuadrat. Dalam artikelnya disebutkan bahwa naive geometry adalah metode geometris sederhana untuk menyelesaikan persamaan kuadrat. Untuk mencari akar-akar persamaan kuadrat menggunakan metode naive geometry, siswa akan melakukan representasi bangun persegi dan persegipanjang yang berhimpit kemudian dimanipulasi sedemikian hingga agar menjadi bangun persegi yang sempurna. Metode ini dipilih agar siswa dapat memahami persamaan kuadrat yang terlihat abstrak menjadi lebih konkrit.

Dengan menerapkan metode naive geometry dalam pembelajaran diharapkan siswa mampu menyelesaikan masalah persamaan kuadrat untuk melatih kemampuan literasi matematika siswa. Penelitian ini bertujuan untuk mengetahui kemampuan literasi matematika siswa SMP setelah memperoleh pembelajaran matematika dengan metode naive geometry pada materi persamaan kuadrat.

\section{METODE PENELITIAN}

Jenis penelitian ini adalah penelitian deskriptif kuantitatif dengan maksud mengetahui kemampuan literasi matematika siswa setelah memperoleh pembelajaran 
dengan metode naive geometry. Penelitian ini dilaksanakan pada tanggal 17-19 Januari 2017 di SMP Ulul Albab Sidoarjo. Sampel penelitian ini siswa kelas VIII-C yang terdiri dari 22 siswa yang memiliki latar belakang kemampuan matematika yang heterogen.

Pembelajaran berlangsung dengan mengembangkan RPP dan LKS yang valid mengacu pada metode naive geometry. Sedangkan untuk pengumpulan data penelitian diperlukan beberapa instrumen pengumpul data. Instrumen pengumpul data tersebut adalah lembar observasi dan tes. Observasi literasi matematis siswa dilaksanakan selama proses pembelajaran. Lembar observasi literasi matematis siswa berisi kolom skor untuk menilai kemampuan literasi matematis siswa untuk indikator berikut, yaitu: (1) Siswa mampu mengekspresikan ide-ide matematika secara lisan, dengan sub indikator: (a) siswa mampu mengajukan pertanyaan selama pembelajaran berlangsung, (b) siswa mampu menyampaikan pendapat selama pembelajaran berlangsung, (c) siswa mampu menyampaikan masalah matematika dengan bahasanya sendiri, (d) siswa mampu mengkonstruksi penyelesaian masalah matematika, (e) siswa mampu menyampaikan penyelesaian masalah matematika, (f) siswa mampu menyampaikan kesimpulan dari penyelesaian masalah; (2) Siswa mampu memanfaatkan teknologi untuk mempermudah perhitungan; dan (3) Siswa mampu menggunakan alat bantu dalam menfasilitasi penyelesaian masalah matematika. Pedoman penskoran observasi literasi matematis siswa ditunjukkan pada Tabel 1.

Tabel 1.

Pedoman Penskoran Observasi Literasi Matematis Siswa

\begin{tabular}{|c|c|c|c|c|c|c|c|c|c|}
\hline \multirow{2}{*}{ No } & \multirow{2}{*}{ Nama Siswa } & \multicolumn{8}{|c|}{ Skor dari Indikator yang Diamati } \\
\hline & & $\mathbf{1 a}$ & $\mathbf{1 b}$ & 1c & 1d & 1e & 1f & 2 & 3 \\
\hline 1 & A & & & & & & & & \\
\hline 2 & B & & & & & & & & \\
\hline 3 & $\mathrm{C}$ & & & & & & & & \\
\hline 4 & $\mathrm{D}$ & & & & & & & & \\
\hline
\end{tabular}

Skala Peskoran:

$0=$ Skor nol jika tidak dilakukan sama sekali oleh siswa

$1=$ Skor satu jika dilakukan, tetapi belum tepat dan sistematis

$2=$ Skor dua jika dilakukan dengan tepat dan sistematis

Selanjutnya, pengambilan data melalui tes dilakukan setelah siswa mengikuti pembelajaran. Tes ini digunakan untuk menilai kemampuan literasi matematika siswa 
setelah mengikuti pembelajaran. Lembar tes literasi matematis berisi dua soal uraian berdasarkan indikator berikut, yaitu: (1) Siswa mampu menganalisis situasi matematis dengan membuat pola sederhana, (2) Siswa mampu menarik kesimpulan dari pola yang telah dibuat, (3) Siswa mampu membuat argumen matematis yang logis dan dapat dipertanggungjawabkan alasannya, (4) Siswa mampu mengekspresikan ide-ide matematika dalam bentuk tulisan, (5) Siswa mampu menyajikan fenomena matematika dalam bentuk model matematis, (6) Siswa mampu melakukan operasi hitung dengan model, (7) Siswa mampu mengidentifikasi masalah matematika, (8) Siswa mampu menyelesaikan masalah matematika, (9) Siswa mampu menerjemahkan gambar menjadi kalimat matematika, (10) Siswa mampu menyajikan ide matematika ke dalam bentuk gambar, (11) Siswa mampu menggunakan simbol matematika dalam membuat pernyataan matematis.

Tabel 2.

Pedoman Penskoran Tes Literasi Matematis Siswa

\begin{tabular}{|c|c|c|c|c|}
\hline No & Indikator Literasi Matematis & Respon Siswa & Skor & $\begin{array}{l}\text { Skor } \\
\text { Max }\end{array}$ \\
\hline \multirow[t]{3}{*}{1} & \multirow[t]{3}{*}{$\begin{array}{l}\text { Menganalisis situasi matematis } \\
\text { dengan membuat pola } \\
\text { sederhana }\end{array}$} & $\begin{array}{l}\text { Tidak mampu menganalisis situasi } \\
\text { matematis dengan membuat pola } \\
\text { sederhana }\end{array}$ & 0 & \multirow{3}{*}{2} \\
\hline & & $\begin{array}{l}\text { Mampu menganalisis situasi } \\
\text { matematis namun pola yang dibuat } \\
\text { belum tepat }\end{array}$ & 1 & \\
\hline & & $\begin{array}{l}\text { Mampu menganalisis situasi } \\
\text { matematis dengan membuat pola } \\
\text { sederhana dengan tepat }\end{array}$ & 2 & \\
\hline \multirow[t]{3}{*}{2} & \multirow{3}{*}{$\begin{array}{l}\text { Menarik kesimpulan dari pola } \\
\text { yang telah dibuat }\end{array}$} & Tidak mampu menarik kesimpulan & 0 & \\
\hline & & $\begin{array}{l}\text { Mampu menarik kesimpulan dari } \\
\text { pola yang telah dibuat namun } \\
\text { kesimpulan tersebut belum tepat }\end{array}$ & 1 & \multirow[t]{2}{*}{2} \\
\hline & & $\begin{array}{l}\text { Mampu menarik kesimpulan dari } \\
\text { pola yang telah dibuat dengan tepat }\end{array}$ & 2 & \\
\hline \multirow[t]{3}{*}{3} & \multirow{3}{*}{$\begin{array}{l}\text { Membuat argumen matematis } \\
\text { yang logis dan dapat } \\
\text { dipertanggung-jawabkan } \\
\text { alasannya }\end{array}$} & $\begin{array}{l}\text { Tidak mampu membuat argumen } \\
\text { matematis yang logis dan dapat } \\
\text { dipertanggungjawabkan alasannya }\end{array}$ & 0 & \multirow{3}{*}{2} \\
\hline & & $\begin{array}{l}\text { Mampu membuat argumen } \\
\text { matematis namun argumennya } \\
\text { belum tepat }\end{array}$ & 1 & \\
\hline & & $\begin{array}{l}\text { Mampu dan tepat dalam membuat } \\
\text { argumen matematis yang logis } \\
\text { serta dapat dipertanggungjawabkan } \\
\text { alasannya }\end{array}$ & 2 & \\
\hline
\end{tabular}




\begin{tabular}{|c|c|c|c|c|}
\hline No & Indikator Literasi Matematis & Respon Siswa & Skor & $\begin{array}{l}\text { Skor } \\
\text { Max }\end{array}$ \\
\hline \multirow[t]{3}{*}{4} & $\begin{array}{l}\text { Mengekspresikan ide-ide } \\
\text { matematika dalam bentuk } \\
\text { tulisan }\end{array}$ & $\begin{array}{l}\text { Tidak mampu mengekspresikan } \\
\text { ide-ide matematika dalam bentuk } \\
\text { tulisan }\end{array}$ & 0 & \\
\hline & & $\begin{array}{l}\text { Mampu mengekspresikan ide-ide } \\
\text { matematika dalam bentuk tulisan } \\
\text { namun masih ada kesalahan }\end{array}$ & 1 & 2 \\
\hline & & $\begin{array}{l}\text { Mampu mengekspresikan ide-ide } \\
\text { matematika dalam bentuk tulisan } \\
\text { dengan tepat }\end{array}$ & 2 & \\
\hline \multirow[t]{3}{*}{5} & $\begin{array}{l}\text { Menyajikan fenomena } \\
\text { matematika dalam bentuk } \\
\text { model matematis }\end{array}$ & $\begin{array}{l}\text { Tidak mampu menyajikan } \\
\text { fenomena matematika dalam } \\
\text { bentuk model matematis }\end{array}$ & 0 & \\
\hline & & $\begin{array}{l}\text { Mampu menyajikan fenomena } \\
\text { matematika dalam bentuk model } \\
\text { matematis namun masih ada } \\
\text { kesalahan }\end{array}$ & 1 & 2 \\
\hline & & $\begin{array}{l}\text { Mampu menyajikan fenomena } \\
\text { matematika dalam bentuk model } \\
\text { matematis dengan benar }\end{array}$ & 2 & \\
\hline \multirow[t]{3}{*}{6} & $\begin{array}{l}\text { Melakukan operasi hitung } \\
\text { dengan model }\end{array}$ & $\begin{array}{l}\text { Tidak mampu melakukan operasi } \\
\text { hitung dengan model }\end{array}$ & 0 & \\
\hline & & $\begin{array}{l}\text { Mampu melakukan operasi hitung } \\
\text { dengan model namun masih ada } \\
\text { kesalahan }\end{array}$ & 1 & 2 \\
\hline & & $\begin{array}{l}\text { Mampu melakukan operasi hitung } \\
\text { dengan model dengan benar }\end{array}$ & 2 & \\
\hline \multirow[t]{3}{*}{7} & $\begin{array}{l}\text { Mengidentifikasi masalah } \\
\text { matematika }\end{array}$ & $\begin{array}{l}\text { Tidak mampu mengidentifikasi } \\
\text { masalah matematika }\end{array}$ & 0 & \\
\hline & & $\begin{array}{l}\text { Mampu mengidentifikasi masalah } \\
\text { matematika namun belum tepat }\end{array}$ & 1 & 2 \\
\hline & & $\begin{array}{l}\text { Mampu mengidentifikasi masalah } \\
\text { matematika dengan benar }\end{array}$ & 2 & \\
\hline \multirow[t]{3}{*}{8} & $\begin{array}{l}\text { Menyelesaikan masalah } \\
\text { matematika }\end{array}$ & $\begin{array}{l}\text { Tidak mampu menyelesaikan } \\
\text { masalah matematika }\end{array}$ & 0 & \\
\hline & & $\begin{array}{l}\text { Mampu menyelesaikan masalah } \\
\text { matematika namun masih ada } \\
\text { kesalahan }\end{array}$ & 1 & 2 \\
\hline & & $\begin{array}{l}\text { Mampu menyelesaikan masalah } \\
\text { matematika dengan benar }\end{array}$ & 2 & \\
\hline \multirow[t]{3}{*}{9} & $\begin{array}{l}\text { Menerjemahkan gambar } \\
\text { menjadi kalimat matematika }\end{array}$ & $\begin{array}{l}\text { Tidak mampu menerjemahkan } \\
\text { gambar menjadi kalimat } \\
\text { matematika }\end{array}$ & 0 & \\
\hline & & $\begin{array}{l}\text { Mampu menerjemahkan gambar } \\
\text { menjadi kalimat matematika } \\
\text { namum kalimat matematikanya } \\
\text { belum tepat }\end{array}$ & 1 & 2 \\
\hline & & $\begin{array}{l}\text { Mampu menerjemahkan gambar } \\
\text { menjadi kalimat matematika } \\
\text { dengan tepat }\end{array}$ & 2 & \\
\hline 10 & Menyajikan ide matematika ke & Tidak mampu menyajikan ide & 0 & 2 \\
\hline
\end{tabular}




\begin{tabular}{|c|c|c|c|c|}
\hline No & Indikator Literasi Matematis & Respon Siswa & Skor & $\begin{array}{l}\text { Skor } \\
\text { Max }\end{array}$ \\
\hline \multirow{7}{*}{11} & dalam bentuk gambar & $\begin{array}{llll}\begin{array}{l}\text { matematika } \\
\text { gambar }\end{array} & \text { ke } & \text { dalam } & \text { bentuk } \\
\end{array}$ & & \\
\hline & \multirow{5}{*}{$\begin{array}{l}\text { Menggunakan simbol } \\
\text { matematika dalam membuat } \\
\text { pernyataan matematis }\end{array}$} & $\begin{array}{l}\text { Mampu menyajikan ide } \\
\text { matematika ke dalam bentuk } \\
\text { gambar namun gambarnya belum } \\
\text { tepat }\end{array}$ & 1 & \\
\hline & & $\begin{array}{l}\text { Mampu menyajikan ide } \\
\text { matematika ke dalam bentuk } \\
\text { gambar dengan tepat }\end{array}$ & 2 & \\
\hline & & $\begin{array}{l}\text { Tidak mampu menggunakan } \\
\text { simbol matematika dalam } \\
\text { membuat pernyataan matematis }\end{array}$ & 0 & \multirow{4}{*}{2} \\
\hline & & $\begin{array}{l}\text { Mampu menggunakan simbol } \\
\text { matematika dalam membuat } \\
\text { pernyataan matematis namun } \\
\text { belum tepat }\end{array}$ & 1 & \\
\hline & & $\begin{array}{l}\text { Mampu menggunakan simbol } \\
\text { matematika dalam membuat } \\
\text { pernyataan matematis dengan tepat }\end{array}$ & 2 & \\
\hline & \multicolumn{3}{|c|}{ Total Skor } & \\
\hline
\end{tabular}

Data hasil observasi literasi matematis dan hasil tes literasi matematis dianalisis dengan tiga langkah. Pertama, data observasi literasi matematis diperoleh dari skor yang diberikan observer berdasarkan pedoman penskoran observasi literasi matematis siswa yang ditunjukkan pada Tabel 1. Data tes literasi matematis diperoleh dari hasil tes siswa yang diskor berdasarkan pedoman penskoran tes literasi matematis siswa yang ditunjukkan pada Tabel 2. Kedua, mengelompokkan hasil observasi dan hasil tes literasi matematis berdasarkan kemampuan siswa. Pengelompokan kemampuan literasi matematika siswa SMP pada materi persamaan kuadrat disajikan pada Tabel 3. Ketiga, menyimpulkan kemampuan literasi matematika siswa SMP pada materi persamaan kuadrat.

Tabel 3.

Kriteria Pengelompokan Kemampuan Literasi Matematika Siswa SMP pada Materi Persamaan Kuadrat

\begin{tabular}{cc}
\hline Total Skor & Kemampuan Literasi Matematika Siswa \\
\hline $19<s \leq 28$ & Tinggi \\
$9<s \leq 19$ & Sedang \\
$0 \leq s \leq 9$ & Rendah \\
\hline
\end{tabular}




\section{HASIL DAN PEMBAHASAN}

Berikut ini disajikan hasil jawaban siswa dengan inisial MDA dan contoh penskorannya.

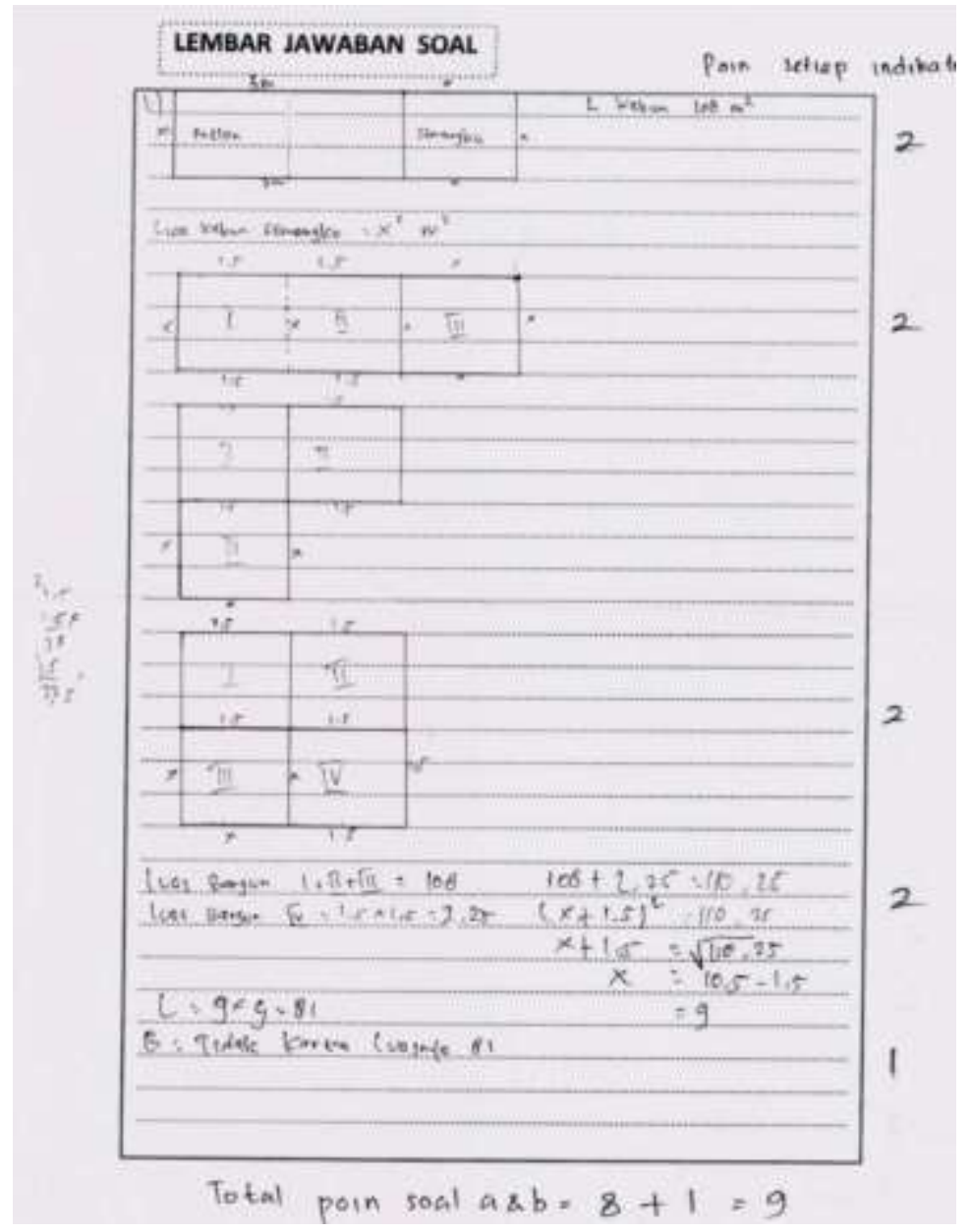

Gambar 1. Jawaban Tes Siswa Inisial MDA

Gambar 1 menunjukkan bahwa MDA mampu menganalisis situasi matematis dengan membuat pola sederhana. Hal ini terlihat dari kemampuannya membedakan bagian kebun semangka dan melon sehingga dia memperoleh skor 2 pada indikator pertama. Selain itu MDA juga mampu menyajikan ide matematika ke dalam bentuk gambar. Hasil gambar MDA menunjukkan bahwa subjek memahami betul metode naive geometry. Oleh karena itu, skor yang diperoleh adalah 2 pada indikator kedua. MDA mampu menggunakan simbol matematika dalam membuat pernyataan matematis sehingga dia memperoleh skor 2 pada indikator ketiga. Hasil gambar pada metode naive geometry mampu MDA terjemahkan menjadi kalimat matematika sehingga dia memperoleh skor 2 pada indikator keempat. MDA telah memberikan jawaban dengan 
tepat pada soal $1 \mathrm{~b}$, tetapi tidak ada penjelasan atau detail argumen yang dibuat. Sehingga hanya memperoleh skor 1 pada indikator kelima. Jadi, total skor yang diperoleh MDA pada soal nomor 1 adalah 9.

Berikut ini rekapitulasi hasil tes dan hasil observasi literasi matematis siswa.

Tabel 4.

Data Hasil Kemampuan Literasi Matematika Siswa

\begin{tabular}{clcccc}
\hline No & \multicolumn{1}{c}{ Nama Siswa } & $\begin{array}{c}\text { Skor } \\
\text { Tes }\end{array}$ & $\begin{array}{c}\text { Skor } \\
\text { Observasi }\end{array}$ & $\begin{array}{c}\text { Total } \\
\text { Skor }\end{array}$ & $\begin{array}{c}\text { Kriteria } \\
\text { Kemampuan }\end{array}$ \\
\hline 1 & AM & 9 & 4 & 13 & Sedang \\
2 & AD & 10 & 5,5 & 15,5 & Sedang \\
3 & BAA & 15 & 4,7 & 19,7 & Tinggi \\
4 & DAKP & 8 & 6 & 14 & Sedang \\
5 & DMP & 13 & 4 & 17 & Sedang \\
6 & DSB & 13 & 3,8 & 16,8 & Sedang \\
7 & EDWR & 8 & 3,8 & 11,8 & Sedang \\
8 & ENAA & 16 & 4,7 & 20,7 & Tinggi \\
9 & FDA & 11 & 3,8 & 14,8 & Sedang \\
10 & FR & 9 & 0,8 & 9,8 & Sedang \\
11 & KAS & 14 & 4,3 & 18,3 & Sedang \\
12 & MDA & 16 & 5,7 & 21,7 & Tinggi \\
13 & MAA & 7 & 0,7 & 7,7 & Rendah \\
14 & MA & 14 & 4,3 & 18,3 & Sedang \\
15 & MAA & 9 & 5,8 & 14,8 & Sedang \\
16 & NIW & 14 & 4,3 & 18,3 & Sedang \\
17 & NE & 16 & 5,8 & 21,8 & Tinggi \\
18 & NPA & 11 & 4,2 & 15,2 & Sedang \\
19 & NIR & 14 & 4,3 & 18,3 & Sedang \\
20 & SBA & 14 & 4,5 & 18,5 & Sedang \\
21 & SR & 5 & 3,5 & 8,5 & Rendah \\
22 & WAAF & 16 & 6 & 22 & Tinggi \\
\hline
\end{tabular}

Berdasarkan Tabel 4, diketahui bahwa 22,73\% siswa berkemampuan literasi matematika tinggi yang berarti cukup banyak siswa yang mampu menyelesaikan masalah persamaan kuadrat dengan baik. 68,18\% siswa berkemampuan literasi matematika sedang yang berarti sebagian besar siswa mampu menyelesaikan masalah persamaan kuadrat dengan cukup baik namun masih terdapat beberapa kesalahan dalam proses perhitungan. 9,09\% siswa berkemampuan literasi matematika rendah yang berarti ada sedikit siswa belum mampu menyelesaikan masalah persamaan kuadrat 
dengan baik. Data di atas menunjukkan bahwa pembelajaran dengan metode naive geometry dapat melatih kemampuan literasi matematis siswa.

Ada beberapa alasan yang menjadi dasar bahwa metode ini dapat melatih kemampuan literasi siswa. Indikator literasi matematis disusun dalam perangkat pembelajaran. Sehingga mampu memaksa siswa melakukan banyak kegiatan yang berkaitan dengan literasi matematis. Adapun kegiatan yang melatihkan kemampuan literasi matematis dalam pembelajaran menggunakan metode naive geometry yaitu mengomunikasikan ide, berargumen, dan melakukan representasi.

Pertama, siswa mampu mengomunikasikan ide saat menggunakan metode naive geometry. Salah satu bentuk komunikasi adalah dengan bertanya. Dalam pembelajaran konvensional jarang sekali siswa mau bertanya kepada guru. Kebanyakan guru yang melontarkan pertanyaan kepada siswa. Namun, pembelajaran tersebut belum bisa memancing siswa untuk bertanya. LKS yang dikembangkan mampu merangsang siswa untuk bertanya. Hal ini terjadi karena belajar aljabar menggunakan bangun geometri adalah hal yang baru bagi siswa. Sehingga mereka tertarik untuk bertanya bagaimana cara mengerjakan LKS tersebut.

Kedua, kelebihan lain dari perangkat yang dikembangkan adalah membiasakan siswa untuk berargumen. Berargumen dalam kegiatan pembelajaran matematika adalah hal yang jarang dilakukan.LKS yang dikembangkan peneliti mampu melatih siswa untuk membuat argumen, salah satu contoh kegiatannya adalah siswa diminta untuk membuat langkah-langkah menentukan akar persamaan kuadrat bentuk $\mathrm{x}^{2}+\mathrm{bx}=$ cdengan metode naive geometry menggunakan bahasanya sendiri.

Ketiga, representasi adalah kegiatan yang biasa dilakukan dalam pembelajaran matematika. Perangkat pembelajaran ini dikatakan berbeda dari biasanya dikarenakan siswa diminta untuk merepresentasikan bentuk persamaan kuadrat menjadi bangun geometris. Hal ini menjadi kelebihan dari metode naive geometry. Jika menilik kembali pada pembelajaran konvensional dalam menyelesaikan persamaan kuadrat siswa dimintamelakukan manipulasi dan operasi aljabar saja. Tidak sedikit siswa yang tak paham dengan proses perhitungan yang dia lakukan. Karena siswa tersebut tidak memahami apa makna dari simbol-simbol yang dia operasikan. Namun, dengan metode naive geometry siswa akan merepresentasikan persamaan kuadrat menjadi bangun geometris kemudian melakukan manipulasi sampai akhirnya dia bisa menentukan akar 
dari persamaan kuadrat tersebut. Dengan metode ini siswa akan lebih memahami makna dari bentuk persamaan kuadrat karena dia mampu merepresentasikannya menjadi bangun geometri.

\section{SIMPULAN DAN SARAN}

Pembelajaran dengan metode naive geometry cukup efektif untuk melatih kemampuan literasi matematika siswa. Sebanyak 22 siswa kelas VIII-C SMP Ulul Albab Sidoarjo yang dijadikan subjek dari penelitian, 5 siswa termasuk dalam kategori siswa berkemampuan literasi matematika tinggi, 15 siswa termasuk dalam kategori siswa berkemampuan literasi matematika sedang, dan 2 siswa termasuk dalam kategori siswa berkemampuan literasi matematika rendah.

Materi persamaan kuadrat yang dikembangkan dalam penelitian ini hanya sampai menemukan rumus kuadratik. Penelitian ini akan lebih sempurna jika metode naive geometry juga digunakan dalam menentukan akar persamaan kuadrat menggunakan pemfaktoran dan kuadrat sempurna.

\section{DAFTAR RUJUKAN}

Aini, I. N. (2013). Meningkatkan literasi matematis siswa melalui pendekatan keterampilan proses matematis (Studi kuasi eksperimen pada siswa madrasah tsanawiyah). Tesis tidak dipublikasikan. Bandung: Universitas Pendidikan Indonesia.

Ayuningtyas, N. (2015). Profil literasi matematis berdasarkan standar pisa siswa kelas X ditinjau dari gaya kognitif visualizer dan verbalizer. Tesis tidak dipublikasikan. Surabaya: Universitas Negeri Surabaya.

Cholidah, D. T. (2014). Profil berpikir siswa SMP dalam memecahkan masalah aljabar ditinjau dari gaya belajar. Surabaya: Universitas Negeri Surabaya.

Dafik, H. S. \& Lestari, N. D. S. (2014). Soal matematika dalam PISA kaitannya dengan literasi matematika dan keterampilan berpikir tingkat tinggi. Prosiding Seminar Nasional Matematika, 19 November 2014. Jember: Pendidikan Matematika Universitas Jember.

Kusaeri, K. (2012). Pengembangan tes diagnostik dengan menggunakan model DINA untuk mendapatkan informasi salah konsepsi dalam aljabar. Disertasi tidak dipublikasikan. Yogyakarta: Universitas Negeri Yogyakarta. 
Kusumawati, I. B. (2015). Pengembangan perangkat pembelajaran dengan pendekatan sejarah naive geometry pada materi persamaan kuadrat di kelas VIII SMP. Jurnal Edukasi, 1, 109-123.

Kusumawati, I. B. (2014). Pengembangan perangkat pembelajaran model kooperatif dengan menggunakan pendekatan saintifik dan metode naïve geometry pada materi persamaan kuadrat di kelas VIII SMP. Tesis tidak dipublikasikan. Surabaya: Universitas Negeri Surabaya.

Nizam. (2016, Oktober 19). Evaluasi ujian nasional - nilai matematika terus jeblok: Nilai UN 1,8 juta siswa SMP dibawah standar. Koran Jakarta. Diakses dari http://www.koran-jakarta.com 